\title{
Solidification Coal Fly Ash on A Textile Factory as Allelochemi to Alternative Portland Cement Wall House Anti-Moss
}

\author{
Prabang Setyono, Suratman \\ Biology Department of Sebelas Maret University, Surakarta, Indonesia \\ E-mail: prabangsetyono@gmail.com,suratmanmipauns@yahoo.com
}

\begin{abstract}
This research for the application of coal waste as fly ash for mixture cement the stonewall anti moss which hypothesis upon which Allelochemi. Using the coal waste represent one of program of environment conservation which is in the form of $3 R$ ( Reuse, Recycle And Reduce), so this research can be made pilot project in development and substance invention of anti moss and make friends with the environment. The research target is identifying moss type in region Surakarta, knowing mixture concentration having technical eligibility of construction and TCLP test ( Toxicity Characteristic Leachate Procedure) and justification of LC50 and LD50. Research was carried out in laboratory by in phases following: casting of Mixture cement and fly ash: test of mechanic strength, test of resilience to moss growth, test of ability adhesive to wall paint, making solid Matrix. Continued by a test Depress to use the Technotest Modena Italy then Test the assimilated: Chemical Ekstraksi in step by step. Fraction 1 until Faction 5, TCLP ( Toxicity Characteristic Leaching Procedure) Standard, TCLP ( Toxicity Characteristic Leaching Procedure) Progressive and TCLP ( Toxycity Characteristic Leaching Procedure) Modification. The Allelochemi form be observed by means of Microscopic observation. The results revealed that moss type found in region of Surakarta: Dicranella heteromalla, Funaria hygrometrica ( Hedwig.), Rhodobryum giganteum ( Schwaegr.) Par., Pogonatum contortum ( Brid.). Mixture prosentase of fly ash which still fulfill the technical standard of concrete building construction is $20-40 \%$. Value LC 50 to animal test the goldfish $8950 \mathrm{ppm}$ and the LD 50 value to animal test the mencit $30,35 \mathrm{mg} / \mathrm{kg}$ BB so that near no toxic. The resistance process of moss growing at coat cement also got concentration $20-40 \%$ through allelochemi mechanism. Ever greater of fly ash prosentase at growth media the moss hence assess the heavy metal accumulation of $\mathrm{Pb}, \mathrm{Cr}, \mathrm{Cd}, \mathrm{Cu}$ and $\mathrm{Zn}$. Process the heavy metal accumulation will generate the effect of allelochemi or resistance of growth moss, but toxic scale or level to kill the optimal moss plant at concentration $20-40 \%$.
\end{abstract}

Keywords-TCLP; LC 50; LD 50; Allelochemi.

\section{INTRODUCTION}

Fly ash (fly ash) and bottom ash (bottom ash) is the solid waste generated from coal burning at power plants. Solid waste is present in large enough quantities. The amount is quite large, so that requires management in order not to cause environmental problems, such as air pollution, aquatic ecosystems and loss of quality.

One of the handling of the environment that can be applied is to utilize the waste for the purposes of building materials such as bricks and paving blocks and farmland properties. However, the utilization of the results are yet to be promoted, as based on the PP. 85 of 1999 concerning amandment to Government Regulation no. 18 of 1999 on Waste Management Hazardous and Toxic Materials, fly ash and bottom ash are categorized as B3 (Bahan Berbahaya dan Beracun) waste because there is heavy metal oxide content of which will have naturally leach and contaminate the environment.
Indonesia is one country that has large coal reserves, which is about 38.8 billion tons of coal of which 70 percent are young, and the remaining 30 percent is high quality coal. This potential should be realized by all levels of society so that optimal management of coal for the benefit of the nation can continue to be monitored and cared for together. Based on the above conditions, coal ash toxicity studies need to be implemented thoroughly. To identify waste as waste B3 test is required characteristics and toxicological tests (TCLP) on the waste.

Efficiency and effectiveness of the building wall paint which is resistant to the influence of moss still need to be reevaluated. It is based on the layer of paint that is relatively dependent on local climatic conditions because the strength of the paint layer which becomes the focus of the anti-moss walls.

Alternative ideas for walls to be durable and permanent in its resistance to moss is to condition the cement wall wallcoverings anti moss. Conditions like these that distinguish the permanence anti lumutnya with just as anti- 
moss coatings in the form of paint. Allelochemic properties (chemical inhibitors) on the growth of algae is a mixture of cement coating the walls of which should be a focus of research.

The research was to apply the waste material of coal as a mixture of cement wall siding anti moss hypothesized as Allelochemi material. Utilization of waste coal is one of the environmental conservation programs in the form of $3 R$ (Reuse, Recycle and Reduce), so this study can be used as a pilot project in the development and discovery of anti-moss materials are cheap and environmentally friendly. Waste coal based PP RI 18 th 1991 with the waste code 223 stated "The list of wastes with code 223 (either the combustion of coal Fly Ash and Bottom Ash) can be expressed as B3 waste toxicity characteristic leacheate Procedure (TCLP) and the test characteristics" Waste coal prior to laboratory testing was still regarded as B3 waste utilization research in order so that is very strategic.

\section{A. Problem}

Problem solving approach to the utilization of waste coal that is by doing research on power allelochemic or chemically induced inhibition of moss plants. Assumption will bring up the issue in the study include:

- How to use waste coal to a mixture of cement wall coating anti moss;

- What is the ratio of waste mixed with cement powder coal which is technically still meet the standard criteria as wall coverings wall.

- How scientific review process through the mechanism of inhibition of moss plants Allelochemic

\section{B. Research Objectives}

The purpose of this study are:

- Utilize waste coal into a mixture of cement wall coating anti moss;

- Knowing the ratio of mixed waste with cement powder coal which is technically still meet the standard criteria as wall coverings wall.

- Knowing the basic scientific process through the mechanism of inhibition of moss plants Allelochemic

\section{LITERATURE REVIEW}

Alelopati phenomenon include all types of chemical interactions between plants, between microorganisms, or between plants and microorganisms [3]. According to [4] such interactions include inhibition and pemacuan directly or indirectly, a chemical compound formed by an organism (plants, animals or microbes) on the growth and development of other organisms. Chemical compounds that play a role in the mechanism is called alelochemic or allelochemic. Alelochemic influence is selective, that affects certain types of organisms but not against other organisms [13].

Alelochemic in plants is formed in various organs, maybe in the roots, stems, leaves, flowers or seeds. Alelokimiaforming organs and species are specific to each species. In general alelochemic are secondary metabolites that are grouped into 14 categories, namely water-soluble organic acids, lactones, long chain fatty acid, quinone, terpenoids, flavonoids, tannins, cinnamic acid and its derivatives, benzoic acid and its derivatives, coumarin, phenols and phenolic acids, non-protein amino acids, sulfides and nucleosides [4, 10]. Alelokimia release generally occurs at certain developmental stages, and levels are influenced by biotic and abiotic stress [4].

Alelochemic in plants is released into the environment and achieve the target organism via evaporation, root exudation, leaching, or decomposition. Each type alelokimia released with a specific mechanism depends on its constituent organs and the shape or chemical properties [4, 10].

Mechanism alelochemic influence (especially that inhibit) the growth and development of organisms (especially plants) target through a series of fairly complex process, but according [4] The process begins at the plasma membrane with the occurrence of chaos structure, modification of membrane channels, or loss of enzyme function ATP-ase. This will affect the absorption and concentration of ions and water which then influence the opening of the stomata and the photosynthetic process. The next obstacle may occur in the process of protein synthesis, pigment and other carbon compounds, and the activities of several fitohormon. Some or all of these obstacles and lead to disruption of cell division and enlargement which ultimately inhibit plant growth and development targets.

Some influence on the activity alelopati plants include:

- Alelopaty compounds can inhibit the absorption of nutrients is to reduce the rate of absorption of ions by plants.

- Some alelopaty inhibit cell division of plant root cells.

- Some alelopaty can inhibit the growth of plants by affecting cell enlargement.

- Several compounds inhibit alelopati influence root respiration.

- Alelopaty compounds inhibit protein synthesis influences.

- Some compounds alelopaty will reduce the permeability of the membrane in plant cells.

- Alelopaty compounds can inhibit enzyme activity.

Coal quality parameters often used is the calorie, moisture content, the content of flying substances, ash content, carbon content, sulfur content, size, and level ketergerusan, in addition to other parameters such as elemental analysis contained in the ash $\left(\mathrm{SiO}_{2}, \mathrm{Al}_{2} \mathrm{O}_{3}, \mathrm{P}_{2} \mathrm{O}_{5}, \mathrm{Fe}_{2} \mathrm{O}_{3}\right.$, etc. $)$, analysis of the composition of sulfur (pyritic sulfur, sulfate sulfur, organic sulfur), and the melting point of ash (ash fusion temperature).

Taking the example of coal-fired power plants (Figure 1), the effects of the above parameters to electric generation equipment is as follows:

- Calories (Calorific Value or CV, the units of cal / g or $\mathrm{kcal} / \mathrm{kg}$ ) $\mathrm{CV}$ is very influential on the operation of pulveriser / mill, coal pipe, and windbox, as well as the burner. The higher the CV the flow of coal per hour was lower so that the speed of coal feeder should be adjusted. For coal with moisture content and level 
ketergerusan the same, then with a high $\mathrm{CV}$ causes pulveriser will operate under its normal capacity (by design), or in other words its operating ratio will be lower.

- Moisture content (Moisture, units of percent) The results for moisture analysis is divided into free moisture (FM) and inherent moisture (IM). The amount of both called for a total moisture (TM). Moisture content affects the amount of primary air consumption. Coal high humidity levels will require more primary air for drying the coal at a temperature specified by the output pulveriser.

- Substance fly (Volatile Matter or VM, the unit of percent) VM womb affects the perfection of combustion and fire intensity. The assessment is based on the ratio between carbon (fixed carbon) with the substance of flying, called fuel ratio (fuel ratio). The higher value of fuel ratio, then the amount of carbon in coal is not burned is also growing. If the comparison is worth more than 1.2, then the ignition will be less good, resulting in the burning velocity decreases.

- The ash content (Ash content, units of percent) The content of ashes will be brought together with the combustion gases through the combustion chamber and the conversion in the form of fly ash (fly ash) that amounted to 80 percent and bottom ash as much as 20 percent. The higher ash content, in general will affect the level of fouling (fouling), wear, and corrosion of equipment that passed.

- Carbon content (Fixed Carbon or FC, the unit of percent) The value obtained through the reduction of carbon levels to 100 with the level of water (moisture), ash content, and the number of flying substances. This value is increasing in line with the level pembatubaraan. Carbon levels and the number of flies are used as calculation agent for assessing the quality of fuel, namely fuel ratio value as described above.

- Levels of sulfur (sulfur content, the unit of percent) Sulfur content in coal is divided into pyritic sulfur, sulfate sulfur and organic sulfur. But in general, the assessment of sulfur content in coal is expressed in Total Sulfur (TS). Sulfur content affects the level of corrosion that occurs on the cold side of air heater element, especially when the working temperature is lower than the dew point of sulfur, in addition to influence the effectiveness of arrest on the equipment electrostatic precipitator ash.

- Size (Coal size) Grain size of coal is limited in the range of fine grain (pulverized coal or coal dust) and coarse grains (lump-coal). The most delicate items to the maximum size of 3 millimeters, while the coarse grain sizes up to 50 millimeters.

- Rate ketergerusan (Hardgrove Index Grindability or HGI) Performance pulveriser or mill is designed in particular HGI values. For lower HGI, its capacity to operate lower than the default value anyway to generate the level of fineness (fineness) of the same.

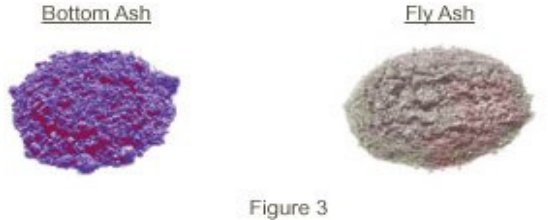

Figure 1. Physical form of bottom ash and fly ash based on the characteristics morphological

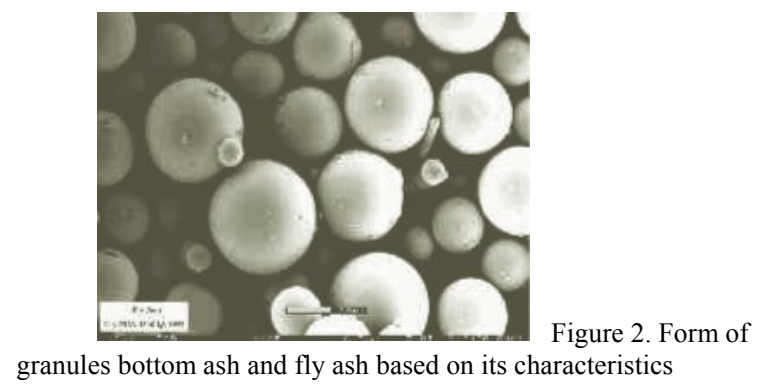

Fly ash / bottom ash produced by fluidized bed system size $100-200$ mesh $(1$ mesh $=1$ hole $/$ inch 2$)$. This size is relatively small and lightweight, while the 20-50 mesh size of bottom ash. In general, the size of the fly ash / bottom ash can be directly utilized in the manufacture of cement as a substitute trass by putting rocks on the cement mill uses compressed air (pneumatic system). Besides used in cement, fly / bottom ash can also be utilized as a mixture of asphalt (ready mix), mixed concrete (concerete) and molded into paving blocks / block. From an empirical study for mixed brick, good composition is as follows:

$\begin{array}{ll}\text { Lime } & : 40 \%: 40 \% \\ \text { Fly ash Fly ash } & : 10 \%: 10 \% \\ \text { Sands } & : 40 \%: 40 \% \\ \text { Cement } & : 10 \%: 10 \%\end{array}$

Environmental issues that arise from the bottom ash using fixed bed or a grate system. Shaped in the form of large chunks. As was mentioned above that the bottom ash was still contain fixed carbon (note: fixed carbon in coal with calorific value $6500-6800 \mathrm{kcal} / \mathrm{kg}$. If the bottom ash is directly discharged into the environment then it will gradually formed methane gas $(\mathrm{CH} 4)$ which at times can catch fire or explode by itself (self-burning and selfexploding). On the other hand, if it would be used in cement it will change the design of the feeder, so that cement plants are not keen to exploit. Fly ash / bottom ash from fluidized bed combustion system can be used for: Fly ash / bottom ash that comes from fluidized bed combustion system can be used for:

- Mixture of acid resistant cement Cement-resistant acid

- Asphalt mixtures (ready mix) and mix asphalt concrete (Ready Mix) and concrete

- Mixture of paving block / brick paving Mixed block / brick

\section{RESEARCH METHOD}

Time and Place

The research was conducted during August-November 2009. Where he did research is UNS Surakarta, Central Laboratory and the Laboratory of Biology of UNS. 


\section{Materials}

Tools: atomic absorption spectrometer (AAS) model Hitachi Polarized Zeeman, compressive strength testing equipment (Technotest Modena Italy), Ember, cetok, Moulds size $5 \times 3 \times 1 \mathrm{~cm}$, Brush, strength tester (Universal Testing Machine), microtome

Materials: Portland Cement Type I production of PT. Semen Cibinong Tbk., Waste Coal textile mills, portland cement type 1, Water, paint walls, plant mikroteknik khemikalia

\section{Procedure}

The study was conducted in the laboratory with the following four stages.

\section{A. Printing a mixture of cement and coal}

Waste Coal cement mixed with various comparisons. The mixture is stirred until homogeneous and then added a little water to form a paste. For comparison also made cement paste without coal mixed with waste. The paste is molded in a mold measuring $5 \times 3 \times 1 \mathrm{~cm}$ and allowed to dry at room temperature. Furthermore, each printout was used as a sample to be tested physical properties.

\section{B. Sample testing of mechanical strength}

Each sample was tested a maximum strength against the compressive force by using a Universal Testing Machine.

\section{Testing the samples in the resistance to mold growth}

Each sample is placed in a fairly humid spot where the spores of plants used to grow moss on the wall. Samples were observed and recorded the changes that occur every day. Observations in the laboratory on the mechanisms allelochemi moss plant with waste coal organological and anatomically.

\section{Tests on samples of wall paint adhesion ability}

Each of the samples painted with wall paint. After the paint was dry enough paint sample results were observed and recorded of the state.

\section{Manufacture of cement-solid matrix of coal ash:}

Comparison of a mixture of coal ash: Cement is $25 \%, 50 \%$ and $75 \%$. Homogeneously mixed. Each comparison is added water in the ratio 1: 2 . The mixture is stirred with a plastic stirrer and printed using concrete molds of size $5 \times 5 \times 5$ $\mathrm{cm} 2$. Avoid formation of air bubbles to knock-knock mold for 1 minute. After a day of solid matrix removed from the mold and then soaked in water for 28 days. Matrix control without the mixture of coal ash to be treated the same. After 28 days solid matrix is ready for testing compressive strength and leaching tests.

\section{Test Press:} Italy.

The matrix was tested using Technotest press Modena Test yielding:

1. Chemical extraction stages. Fraction 1 to fraction 5

2. TCLP (Toxycity Characteristic Leaching Procedure) Standard
3. TCLP (Toxycity Characteristic Leaching Procedure) Progressive

4. TCLP (Toxycity Characteristic Leaching Procedure) Modification

Microscopic observations on the nature of the coal waste Moss Allelopati:

Moss spores and observed the effectiveness of waste coal properties allelopati textile mill of the moss plant. Observations include the character and nature of the anatomical organological moss plants.

\section{Result Analysis}

The results of tests on samples that have been made compared to the results and determined the optimum size ratio between cement and waste coal fly ash in the mixture with a descriptive analysis. Tests for heavy metal content in the media and moss analysis was performed by AAS.

\section{RESULT AND DISCUSSION}

The research was done in stages include taxonomic studies then continued study solidification of waste coal fly ash mixed with cement according to standard wall construction and toxicity studies of waste coal fly ash with various concentrations. Taxonomic studies of mosses found in the Surakarta region shows that there are 4 types of moss. The identification results are as follows: Dicranella heteromalla, Funaria hygrometrica (Hedwig.), Rhodobryum giganteum (Schwaegr.) Par., Pogonatum contortum (Brid.). Research in the laboratory scale this is exploratory research that is so taking the proportion of treatment $20 \%, 40 \%, 60 \%$ and $80 \%$ is a proportion based on the equitable distribution. Proportion based on the percentage of the mixture as a substitute for cement lining a wall of sand is expected to have a smooth texture according to the nature of waste coal fly ash. The test results prompted a test press or a mixture of waste coal and cement are as in Table 1 below:

TABLE I

TEST Results (TEST PRESS) TO PRINT CONCRETE MIX COAL WASTE FLY ASH

\begin{tabular}{|l|l|l|l|}
\hline No. & $\begin{array}{l}\text { Treatment } \\
\text { (concentration-ppm) }\end{array}$ & $\begin{array}{l}\text { Power / } \\
\text { Strength } \\
\text { concrete } \\
\text { mixture }\end{array}$ & Description \\
\hline 1. & $\begin{array}{l}\text { Control (without any } \\
\text { mixture of coal powder) }\end{array}$ & $\begin{array}{l}150 \\
\mathrm{Kg} / \mathrm{cm} 2\end{array}$ & \\
\hline 2. & $\begin{array}{l}\text { Mixture } 80: 20 \quad(80 \% \\
\text { cement }: 20 \% \text { powder } \\
\text { coal) }\end{array}$ & $\begin{array}{l}104 \\
\mathrm{Kg} / \mathrm{cm} 2\end{array}$ & $\begin{array}{l}\text { relatively equal } \\
\text { mixture of 1: 1 } \\
\text { (Cement: Sand) }\end{array}$ \\
\hline 3. & $\begin{array}{l}\text { Mixture } 60: 40 \quad(60 \% \\
\text { cement }: 40 \% \text { powder } \\
\text { coal) }\end{array}$ & $\begin{array}{l}81,2 \\
\mathrm{Kg} / \mathrm{cm} 2\end{array}$ & $\begin{array}{l}\text { relatively equal } \\
\text { mixture of 1: } \\
\text { (Cement: Sand) }\end{array}$ \\
\hline 4. & $\begin{array}{l}\text { Mixture } 40: 60 \quad(40 \% \\
\text { cement }: 60 \% \text { powder } \\
\text { coal) }\end{array}$ & $\begin{array}{l}50,3 \\
\mathrm{Kg} / \mathrm{cm} 2\end{array}$ & $\begin{array}{l}\text { relatively equal } \\
\text { mixture of 1: } \\
\text { (Cement: Sand) }\end{array}$ \\
\hline 5 & $\begin{array}{l}\text { Mixture } 20: 80(20 \% \\
\text { cement }: 80 \% \text { powder } \\
\text { coal) }\end{array}$ & $\begin{array}{l}15,7 \\
\mathrm{Kg} / \mathrm{cm} 2\end{array}$ & $\begin{array}{l}\text { Under } \\
\text { construction } \\
\text { technical } \\
\text { standards }\end{array}$ \\
\hline
\end{tabular}

Based on the results above can be described that the percentage of waste coal fly ash mixture is below standard, ie at $80 \%$ so that the composition of the mixture is not 
recommended as a mixture to be applied in building construction as wall coatings. At a concentration of $20 \%$ $60 \%$ within the tolerance limits the wall linings of construction standards, but it is technically at a concentration of $20 \%$ is a standard mixture of waste coal fly ash and cement are the best.

After the search process the composition of the mixture of waste coal fly ash and cement a good standard of construction is necessary to note aspects of the toxicity of waste coal fly ash aggregate via the TCLP test (Toxicity Characteristic leachate procedure) as a standard condition B3 waste processing to be converted into building materials products. TCLP test results are in accordance with the table below:

TABLE II

TCLP TEST RESULTS (CHARACTERS TOXIC) WASTE COAL FLY ASH BY U.S. EPA METHOD D1311

\begin{tabular}{|l|l|l|l|l|}
\hline No. & Unsur & $\begin{array}{l}\text { TCLP Result } \\
(\mathrm{ppm})\end{array}$ & $\begin{array}{l}\text { Standard } \\
(\mathrm{ppm})\end{array}$ & Description \\
\hline 1. & $\mathrm{~Pb}$ & 2,4 & 5,0 & Under the standard \\
\hline 2. & $\mathrm{Zn}$ & 3,1 & 50,0 & Under the standard \\
\hline 3. & $\mathrm{As}$ & $\mathrm{n} \mathrm{t}$ & 5,0 & Under the standard \\
\hline 4. & $\mathrm{Cr}$ & $\mathrm{n} \mathrm{t}$ & 5,0 & Under the standard \\
\hline 5. & $\mathrm{Cd}$ & $\mathrm{n} \mathrm{t}$ & 1,0 & Under the standard \\
\hline 6. & $\mathrm{Cu}$ & 1,7 & 10,0 & Under the standard \\
\hline
\end{tabular}

$\mathrm{n} \mathrm{t}=$ not detected

Reviewing the results of TCLP testing on the heavy metals detected are the elements $\mathrm{Pb}, \mathrm{Zn}$ and $\mathrm{Cu}$ although still below standard. Metal elements $\mathrm{As}, \mathrm{Cr}$ and $\mathrm{Cd}$ was not detected does not mean no but because levels are so small as negligible. The content of each element is metal mining coal with a different source then the composition element levels will also differ according to the process of coal formation. TCLP test is a test of character of a toxic material that has the power potential of leachate / pelindiannya. Through the TCLP test's potential B3 element (hazardous and toxic materials) to affect the leaching process can be detected. Coal fly ash waste by TCLP test was still below standard so there are opportunities to be used as building materials and others.

The toxicity of a compound of the organism is measured by the LC-50\% $-96 \mathrm{~h}$ and LD-50 test animals with goldfish and mice. The results of acute toxicity tests on test animals are as follows:

TABLE III

THE RESULTS OF TOXICITY TESTS OF WASTE COAL FLY ASH

\begin{tabular}{|l|l|l|l|}
\hline $\begin{array}{l}\text { NAME } \\
\text { ORGANISMS }\end{array}$ & $\begin{array}{l}\text { VALUE } \\
\text { LC-50 }\end{array}$ & $\begin{array}{l}\text { VALUE } \\
\text { LD-50 }\end{array}$ & DESCRIPTION \\
\hline Goldfish & $8950 \mathrm{ppm}$ & - & Almost non-toxic \\
\hline Mouse & - & $\begin{array}{l}30,35 \mathrm{mg} / \mathrm{Kg} \\
\text { BB }\end{array}$ & $\begin{array}{l}\text { Relatively } \\
\text { harmless } \\
\text { According to PP } \\
\text { RI no.74 th.2001 }\end{array}$ \\
\hline
\end{tabular}

The 50-96 hour LC value of waste coal fly ash to carp is $8950 \mathrm{ppm}$ so it can be concluded that the compound is virtually non-toxic. Animal tests have higher levels of mouse has a LD 50 value of $30.35 \mathrm{mg} / \mathrm{kg} \mathrm{BW}$, when compared with PP RI no. 74 th 2001, it can be classified as relatively non-toxic compounds such. This indicates that the waste coal fly ash can be utilized as an ingredient in building materials especially cement mixture that moss resist. Observations of toxicity was also conducted based on its interaction with moss plants. Percentage values based on composition percentage of deaths moss mixture of waste coal fly ash with cement are shown in the following table:

TABLE IV

PERCENTAGE OF DEATHS MOSS ON NORMAL MOISTURE TREATMENT ON THE TEMPERATURE: $28-29^{\circ} \mathrm{C}$ AND HUMIDITY: $75-80 \%$

\begin{tabular}{|c|c|c|c|}
\hline Treatment & $\begin{array}{l}\text { Repli } \\
\text { catio } \\
\text { n }\end{array}$ & $\begin{array}{l}\% \\
\text { Death }\end{array}$ & Description \\
\hline $\begin{array}{l}20 \% \text { Waste : } \\
80 \% \text { Cement }\end{array}$ & $\begin{array}{l}1 \\
2 \\
3\end{array}$ & $\begin{array}{l}21 \\
28 \\
7\end{array}$ & $\begin{array}{l}\text { Thalus more brown color. } \\
\text { Moss has been attached to the } \\
\text { media. }\end{array}$ \\
\hline $\begin{array}{l}40 \% \text { Waste : } \\
60 \% \text { Cement }\end{array}$ & $\begin{array}{l}1 \\
2 \\
3\end{array}$ & $\begin{array}{l}29 \\
23 \\
30\end{array}$ & $\begin{array}{l}\text { Thalus more brown color. } \\
\text { Moss has been attached to the } \\
\text { media. }\end{array}$ \\
\hline $\begin{array}{l}\text { 60\%Waste : } \\
40 \% \text { Cement }\end{array}$ & $\begin{array}{l}1 \\
2 \\
3\end{array}$ & $\begin{array}{l}1 \\
5 \\
3\end{array}$ & $\begin{array}{l}\text { Thalus dominant color is green, } \\
\text { but on the edge of the talus } \\
\text { brownish color. } \\
\text { Moss has been attached to the } \\
\text { media. }\end{array}$ \\
\hline $\begin{array}{l}80 \% \text { Waste : } \\
20 \% \text { Cement }\end{array}$ & $\begin{array}{l}1 \\
2 \\
3\end{array}$ & $\begin{array}{l}1 \\
3 \\
2\end{array}$ & $\begin{array}{l}\text { Thalus dominant color is green, } \\
\text { lush. } \\
\text { Moss has been attached to the } \\
\text { media. } \\
\text { There is a new individual. }\end{array}$ \\
\hline
\end{tabular}

TABLE V

LEVELS OF HEAVY METALS IN DIFFERENT MEDIA COMPARISONS

\begin{tabular}{|c|c|c|c|c|c|c|}
\hline \multirow[b]{2}{*}{ No } & \multirow[b]{2}{*}{ Sample } & \multicolumn{5}{|c|}{ Content/Consentration of Heavy Metal (ppm) } \\
\hline & & $\begin{array}{l}\text { Timbal } \\
(\mathrm{Pb})\end{array}$ & $\begin{array}{l}\text { Krom } \\
(\mathrm{Cr})\end{array}$ & $\begin{array}{l}\text { Cuprum } \\
\text { (Cu) }\end{array}$ & $\begin{array}{l}\text { Cadmium } \\
\text { (Cd) }\end{array}$ & $\begin{array}{l}Z n \\
\text { (Seng) }\end{array}$ \\
\hline \multicolumn{7}{|c|}{ Media } \\
\hline 1 & Control & nd & nd & nd & nd & nd \\
\hline 2 & F20 & 43.870 & 31.760 & 20.832 & 4.500 & 52.495 \\
\hline 3 & $\mathrm{~F} 40$ & 39.550 & 35.190 & 20.125 & 4.050 & 70.267 \\
\hline 4 & F60 & 36.587 & 39.762 & 20.907 & 3.882 & 66.157 \\
\hline 5 & F80 & 35.317 & 29.537 & 16.285 & 2.655 & 121.62 \\
\hline
\end{tabular}

Control $=100 \%$ cement; F20 $=20 \%$ fly ash : $80 \%$ Cement; F $40=40 \%$ fly ash : $60 \%$ Cement; F60 $=60 \%$ fly ash : $40 \%$ Cement; F $80=80 \%$ fly ash : $20 \%$ Cement : nd=not detected

TABLE VI

LEVELS OF HEAVY METALS ON MOSS IN DIFFERENT MEDIA COMPARISONS

\begin{tabular}{|l|l|l|l|l|l|l|}
\hline & Sample & $\begin{array}{l}\text { Timbal } \\
(\mathrm{Pb})\end{array}$ & $\begin{array}{l}\text { Krom } \\
(\mathrm{Cr})\end{array}$ & $\begin{array}{l}\text { Cuprum } \\
(\mathrm{Cu})\end{array}$ & $\begin{array}{l}\text { Cadmium } \\
(\mathrm{Cd})\end{array}$ & $\begin{array}{l}\mathrm{Zn} \\
(\text { Seng })\end{array}$ \\
\hline 1 & Control & nd & nd & nd & nd & nd \\
\hline 2 & LF20 & 16.430 & 0.805 & 15.196 & 1.088 & 71.365 \\
\hline 3 & LF40 & 17.390 & 1.525 & 18.686 & 1.265 & 86.236 \\
\hline 4 & LF60 & 20.270 & 5.995 & 23.295 & 1.668 & 93.646 \\
\hline 5 & LF80 & 33.933 & 28.301 & 29.771 & 1.950 & 102.53 \\
\hline
\end{tabular}

Control $=100 \%$ cement; LF20 $=20 \%$ fly ash : $80 \%$ cement; LF $40=40 \%$ fly ash : $60 \%$ cement; LF $60=60 \%$ fly ash : $40 \%$ cement; LF $80=80 \%$ fly ash : $20 \%$ cement

Based on the above data indicate that the concentration of waste coal fly ash cement is getting bigger and the smaller the concentration of the moss plant mortality rate gets smaller. This suggests that the effective concentration of a mixture of coal waste with cement ranged between $20-40 \%$ effective in inhibiting the growth of moss to the deadly scale. If the reference data from the test results press the mixture of coal waste $20-40 \%$ also show results that approach the standard construction of a wall, so that the 
concentration of the mixture is highly recommended by researchers as an effective and efficient concentration to produce a wall coating that moss resists.

Based on the above table it can be shown that the greater percentage of fly ash content of the moss growing on the medium then the value of accumulated heavy metals $\mathrm{Pb}, \mathrm{Cr}$, $\mathrm{Cd}, \mathrm{Cu}$ and $\mathrm{Zn}$ are also getting bigger. The process of accumulation of heavy metals will cause effects allelochemi or algae growth inhibition, but on a scale of toxic or lethal levels moss plants on the optimal concentration of $20-40 \%$. Saturation process of accumulation of heavy metals in the mechanism of the inhibitory effect due to algae growth in high concentrations in the $60-80 \%$ concentration levels of toxic fly ash tends to decrease.

\section{CONCLUSIONS}

From the results of research conducted can be inferred types of moss found in the region of Surakarta Dicranella heteromalla, Funaria hygrometrica (Hedwig.),Rhodobryum giganteum (Schwaegr.) Par., Pogonatum contortum (Brid.) LC 50 value of the test animals carp $8950 \mathrm{ppm}$ and LD 50 values against animal testing mice were $30.35 \mathrm{mg} / \mathrm{kg}$ of BB so it can be concluded almost non-toxic. Percentage of waste coal fly ash mixture that still meets the technical standards of building construction wall is $20-40 \%$. The process of inhibition of growth of moss on a layer of cement is also found at a concentration of $20-40 \%$ through allelochemi mechanism. The greater the percentage of fly ash content of the moss growing on the medium then the value of accumulated heavy metals $\mathrm{Pb}, \mathrm{Cr}, \mathrm{Cd}, \mathrm{Cu}$ and $\mathrm{Zn}$ are also getting bigger. The process of accumulation of heavy metals will cause effects allelochemi or algae growth inhibition, but on a scale of toxic or lethal levels moss plants on the optimal concentration of $20-40 \%$.

\section{ACKNOWLEDGMENT}

We would like to thank Biological Laboratory,Sebelas Maret University for permits to use the all facility.

\section{REFERENCES}

[1] Caamal-Eldonado JA, Jimenez-Osornio JJ, Torres-Barragin A, Anaya AL. 2001. The use of allelopathic legume cover and mulch species for weed control in cropping system. Agronomy Journal. 93: 1. $27-36$.

[2] Cruz, A. 1995. Spesimen Biologi: Pembuatan dan Pengawetan HEDS-USAID, Jakarta.

[3] Einhellig FA. 1995. Allelopathy: Current status and future goals. Dalam Inderjit, Dakhsini KMM, Einhellig FA (Eds). Allelopathy. Organism, Processes and Applications. Washington DC: American Chemical Society. Hal. $1-24$.

[4] Einhellig FA. 1995. Mechanism of action of allelochemicals in allelopathy. Dalam Inderjit, Dakhsini KMM, Einhellig FA (Eds) Allelopathy. Organism, Processes and Applications. Washington DC: American Chemical Society. Hal. 96-116.

[5] http://fp.uns.ac.id/ hamasains/dasarperlintan-4.htm

[6] JCOAL, Coal Science Handbook, Japan Coal Energy Center, 2005.

[7] JCOAL, Kuri-n ni Riyou Sareru Sekitan, Japan Coal Energy Center, 2004.

[8] Plucknert, Winkelmann DI. 1992. Technology for sustainable agriculture. Scientific American. 182 - 186.

[9] Reijntjes C, Haverkort B, Waters-Bayers A. 1999. Pertanian Masa Depan. Diterjemahkan oleh Y. Sukoco. Yogyakarta: Kanisius.

[10] Rice EL. 1984. Allelopathy. Second Edition. Orlando FL: Academic Press

[11] Sukandarrumidi, Batubara dan Gambut, Gadjah Mada Univ. Press, 1995.

[12] WCI, Coal Facts 2005, World Coal Institute, October 2005.

[13] Weston LA. 1996. Utilization of allelopathy for weed management in agrosystem. Agronomy Journal. 88:6. 860 - 866 . 